\title{
Impact of public debt on growth in Belt \& Road countries -Pre and Post Analysis of Financial Crisis 2007-2008
}

\begin{abstract}
Waqas $\mathrm{Ali}^{1}$, Hameed Khan ${ }^{2 \mathrm{~b}^{*}}$, Umair Khan ${ }^{3}$
Abstract

The study seeks to investigate the role of external debt on the growth performance of Belt \& Road countries for the pre \& post financial crisis period. Using panel data methodologies like fixed effect model and GMM, the study finds a significant negative relationship between external debt and economic growth. Similarly, various specifications are estimated for robustness check like dividing the period into sub-periods, dividing the countries according to continent basis, and applying the generalized method of moment's techniques. The robustness checks confirm the negative relationship between debt and economic growth.
\end{abstract}

Keywords: External debt, BRI, growth

JEL Classification: C33; H63; O43

DOI: $10.7176 /$ RJFA/10-18-18

Publication date:September $30^{\text {th }} 2019$

\section{Introduction}

The financial crisis2007-2008 affects the fiscal imbalances of many economies of the world. The crisis originated with the bankruptcy of Lehman Brothers, and its spillover effects are felt by almost all the globalized world. The economies of the Belt \& Road Initiative (BRI) also affect by this financial crisis. To control its effect, governments have taken some fiscal and monetary measure to control the effects. Therefore, the study investigates the role of external debt in economic growth during the pre and post era of financial crisis for BRI countries.

Role of government debt in economic growth gave rise to a controversy when the findings of the Reinhart and Rogoff (2010) came into light. The slower economic performance and controversy further fueled the debate when mistakes in their study were highlighted. The debate still continues regarding this macroeconomic issue. The governments usually print money, impose taxation, and other important measures to curb the slower economic performance. For politicians and social scientists, Buchanan (1966) ask an important question-e.g., "When and who pays for public expenditure financed by debt issue, instead of by taxation or the printing of money?"

The neoclassical growth theories argues that capital mobility enhance the economic performance since in their initial stages of developments the countries don't have sufficient amount of resources-e.g., investment opportunities and capital stock (Chowdhury, 2001). The external debt positively contributes the economic growth so far it is used for investment. Similarly, the findings of Burnside and Dollar (2000) also report that debt can enhance the growth performance under some specific conditions. However, economic growth and investment may also be adversely affected by higher volume of debt. 'Debt overhang' theory states that whenever the volume of debt is high enough to repay it, then it leads to the depressing of investment by anticipating increased cost of debt servicing (Krugman, 1988; Karagol, 2002). This is called the crowding out effect of government debt because limited amount of money left for investment and it leads to adverse economic growth.

The previous studies didn't convey the clear picture of government debt \& economic growth relationship. Poirson et al., (2004); and Poirson et al., (2002); Cohen (1993) didn't find significance evidence to support the view that government debt can crowd out the investment. On the other hand, the findings of several studies report that debt can adversely affect the investment and economic growth (Nguyen et al., 2003; Chowdhury, 2001; Elbadawi, 1999). Therefore, our contribution is to provide further insights into the debt and growth literature by exploring

\footnotetext{
${ }^{1}$ MS Scholar at School of Economics, Jilin University, Changchun, China <waqas.ali.dik@live.com>

2 P.hD Scholar at School of Economics, Jilin University, Changchun, China. ${ }^{b}$ Kohat University of Science \& Technology, Kohat, Pakistan. Corresponding Author <hameed.qec@gmail.com>

${ }^{3}$ Kohat University of Science \& Technology, Kohat, Pakistan < umairk623@gmail.com>
} 
the impact external debt on economic growth in newly established economic block i.e., Belt \& Road Initiative (BRI). Furthermore, various robustness checks are applied to look more closely the specific relationship i.e, time period specifications, grouped \& ungrouped data, and static as well as dynamic panel data analysis (GMM).

The remaining of this paper is organised as follows. Section II provides a brief overview of the debt and growth condition in BRI countries, section III describes the data and estimation methodology, section IV reports the empirical results, and finally section $\mathrm{V}$ presents the concluding remarks of the study.

\section{Overview of debt and growth in BRI countries}

Like all other economies, the financial crisis of also affect the BRI countries. Figure -1 shows that along the graphical representation of the relationship between external debt and GDP growth rate for the continents being the members of BRI. The challenging position to revive their economies, the governments of the BRI countries demanded for the external debt as a source to finance their industries by boosting up the aggregate demand. However, the negative effects of external debt are also evident. The figure- 1 shows that Asian and European countries suffer in respect of GDP growth rate after the post shocks of financial crisis, however, it did not impact African and South American countries a lot.

Similarly, Table-1 reports the statistical summary results of GDP growth rate, external debt, domestic investment, inflation, urbanization, debt servicing, and trade openness. However, we focus on our variable of interest like growth and external debt. The mean value of external debt is 29.28, while standard deviation is 24.1. Similarly the growth statistics reports a strange and interesting picture. The mean value is 4.96 and standard deviation is 5.23, whereas, the minimum value is $-37.14 \%$ which is the value relates to Yemen in 2015 . Due to war conditions in Yemen the GDP growth rate drastically down. Similarly, the max value for this variable is $54.15 \%$ which relates to Iraq in 2004.

Similarly, Table-2 reports the result correlation matrix. Here one can see that there is positive relationship between GDP growth and domestic investment, which is in line with the economic theory. The results show the positive relation between growth and trade openness as well as the same relationship between growth and urbanization. On the other hand, the relationship between growth and other variables like external debt, inflation and debt is negative which is in line with the theoretical expectations.

Figure-1. GDP growth and external debt in BRI countries

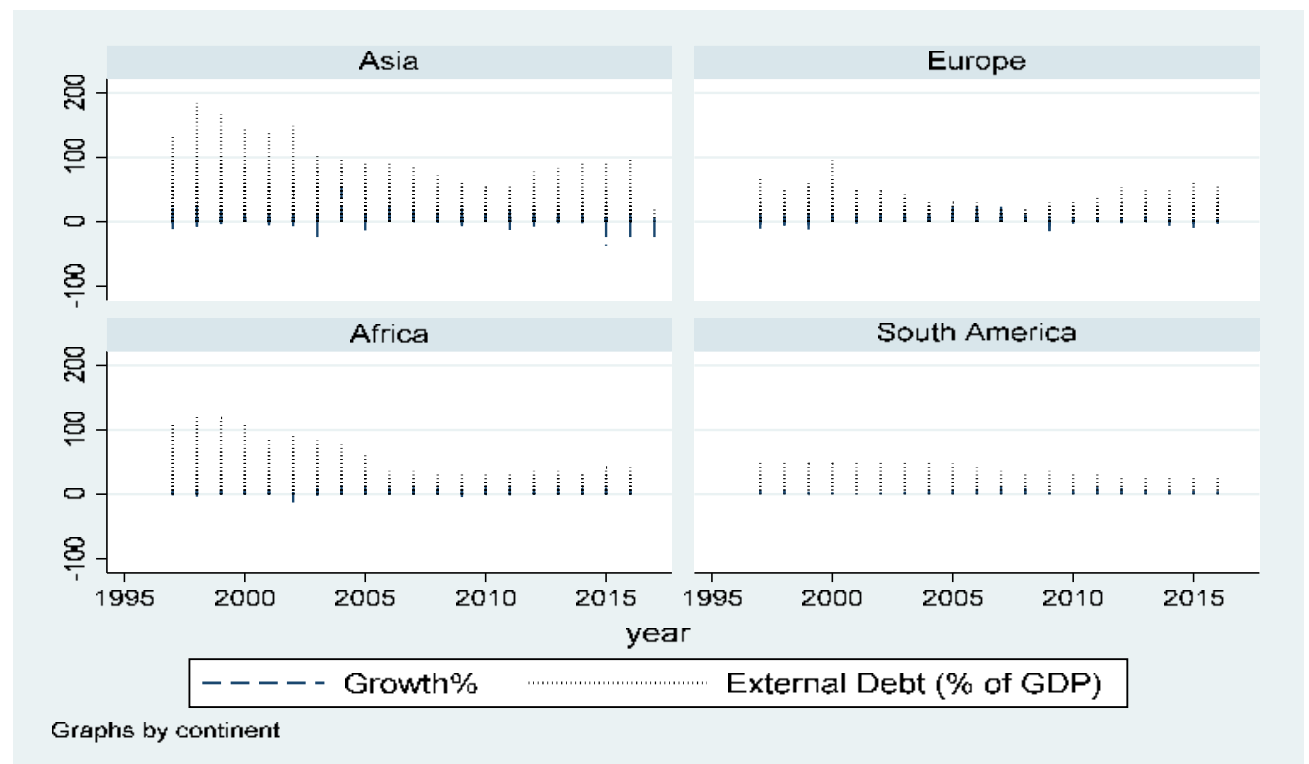

Source: WDI Database, authors' calculations. 
Table-1. Summary statistics

\begin{tabular}{|l|c|c|c|c|}
\hline Variable & Mean & Std. Dev. & Min & Max \\
\hline Growth & 4.96 & 5.23 & -37.14 & 54.15 \\
\hline Domestic investment & 22.98 & 9.87 & 23.74 & 68.02 \\
\hline External debt & 29.28 & 24.17 & 0.15 & 184.61 \\
\hline Debt servicing & 6.69 & 6.32 & 0.21 & 36.70 \\
\hline Inflation & 77.83 & 41.70 & 4.36 & 307.49 \\
\hline Trade openness & 81.68 & 39.92 & 0.17 & 217.72 \\
\hline Urbanization & 49.20 & 19.14 & 11.83 & 90.50 \\
\hline
\end{tabular}

Table-2 Correlation matrix

\begin{tabular}{|l|c|c|c|c|c|c|c|}
\hline & Growth & $\begin{array}{c}\text { Domestic } \\
\text { investment }\end{array}$ & $\begin{array}{c}\text { External } \\
\text { debt }\end{array}$ & $\begin{array}{c}\text { Debt } \\
\text { servicing }\end{array}$ & Inflation & $\begin{array}{c}\text { Trade } \\
\text { openness }\end{array}$ & Urbanization \\
\hline Growth & 1 & & & & & & \\
\hline Domestic investment & 0.14 & 1 & & & & & \\
\hline External debt & -0.03 & -0.08 & 1 & & & & \\
\hline Debt servicing & -0.17 & -0.03 & 0.38 & 1 & & & \\
\hline Inflation & -0.04 & 0.20 & -0.20 & -0.04 & 1 & & \\
\hline Trade openness & 0.05 & 0.25 & 0.04 & -0.17 & 0.09 & 1 & \\
\hline Urbanization & 0.12 & 0.11 & -0.24 & 0.05 & 0.03 & 0.29 & 1 \\
\hline
\end{tabular}

\section{Data and estimation methodology}

1- Data

To assess the impact of external debt in pre and post financial crisis 2008 , the data with its sources are given in the Table-3.

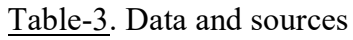

\begin{tabular}{|c|c|c|c|}
\hline S\# & Name of variable & Data source & Comment \\
\hline 1 & Investment $(D I)$ & WDI & Gross capital formation as percentage of GDP \\
\hline 2 & External debt $(E D T)$ & WDI & $\begin{array}{l}\text { Public and publicly guaranteed external debt as percentage of } \\
\text { GDP }\end{array}$ \\
\hline 3 & Debt Servicing $(D S)$ & WDI & $\begin{array}{l}\text { Debt servicing of Public and Publicly guaranteed external debt as } \\
\text { percentage of Exports. }\end{array}$ \\
\hline 4 & Openness $(O P E N)$ & WDI & (Exports + Imports)/GDP*100 \\
\hline 5 & Urbanisation $(U R B)$ & WDI & Urban population as percentage of total population \\
\hline 6 & Inflation $(I N F)$ & WDI & Consumer Price Index \\
\hline 7 & GDP growth rate $(G R O W)$ & WDI & GDP growth rate \\
\hline
\end{tabular}

\section{2- $\quad$ Model specification}

In this paper we examine the impact of various indicators of debt burden on the economic growth of South Asian countries. We also examine, whether this relationship is linear or not. For estimation, the model is specified as;

$$
\operatorname{grow}_{i t}=\alpha_{i t}+\sum_{j=1}^{k} \gamma X_{i t j}+\sum_{m=1}^{p} \delta D E B T_{i t m}+\eta_{t}+v_{i}+\varepsilon_{i t}
$$

Where grow is the GDP growth, $\mathrm{X}_{i t j}$ is set of control variables, DEBT is various terms of external used in this. Subscripts $i$ and $t$ represent panel and time dimension, while $\eta$ and $v$ denote time specific and country specific effects. 


\section{3- Estimation methodology}

By using the data of 52 BRI countries (due to non-availability of data some countries are excluded) for the time period 1997-2017, we estimate the growth model. Most of the studies use Fixed Effects/Random Effects models in order to capture the effect of country-specific factors. In this study, we estimate the model by applying fixed effect and random effect models and the feasible model has been selected by using Hausman test. However, since there is a likelihood of endogeneity in the panel data, so to get robust results the Generalised Method of Moments (GMM) estimator has been applied (see Enders, 2004 and Baltagi, 2005). The tricky issue in GMM methodology is to select valid instruments/moments. No rule of thumb exists in instruments' selection. For this purpose various tricks has been discussed by Murray (2006). In this study, the lagged values of independent variables have been used as instruments.

The mentioned estimation techniques in this study are applied on aggregated and disaggregated data (by decomposing global sample into various groups like Asia, Europe, Africa, and South America) for various time periods (1997-2017, 1997-2006, and 2007-2017). We combine Panama and Bolivia into one group i.e., South America. The intension for this disaggregation is to watch closely the effect of financial crisis on Belt and Road countries. We exclude the squared of external debt for its too much lower and insignificant magnitude. In this paper, we use stata 15 for estimations.

\section{Empirical results}

1- Specification for different continents from 1997-2017

Table-4 reports the estimation results of fixed effect model, random effect model, and GMM for grouped (we call it group-I, represents 52 countries) and ungrouped data (i.e., Asia, Europe, Africa, and South America, henceforth we denote as group-II, group-III, group-IV, group-V respectively) for the time period of 1997-2017. From groupI to IV, the reasonable technique is fixed effect suggested by Hausman test, however, for group-V random effect is appropriate option.

Negative relationship between external debt and GDP growth is confirmed in this study for group-I, group-IV and group-V countries, however the coefficients are not significant for group-II and group-III countries though the values are negative. The likely reason for the negative relation is that when domestic resources are mobilized to repay the external debt, then enough resources are unavailable for investment. Hence, the 'overhang effect' is confirmed. Similarly, the coefficients of debt-servicing in all groups of countries are negative and significant which implies the existence of crowding out effect.

The positive role of investment in GDP growth is confirmed in this study whereby the coefficients are positive and significant for group-I and group-III countries, however, the coefficients remains insignificant for group-II, group-IV and group-V countries though the values are positive. The results are according with the findings of other studies-e.g., Mankiw, Romer, and Weil (1992) and Poirson et al., (2002). Similarly, for all group of countries, the growth enhancing effect of trade openness is confirmed. The results are consistent with findings of other studiese.g., Lucas (1988) and Poirson et al., (2002). The likely growth enhancing effect of trade openness seems to be due to the increased productivity and competitiveness.

The results of urbanization for all the groups are significant and positive which is according to the new growth models. The proponents of the theory argues that cities are hubs of creativity innovation, and institutions. According to Haque \& Nayab,( 2006) economic growth may be achieved through the increased urbanization. The positive role of urbanization may also be clued that with the passage of time rural population migrated to the urban areas and contributed the economic growth of a country.

The estimation results for the period of 1997-2017 give a blur and ambiguous picture about the impact of inflation on economic growth. The economic theory of inflation states that if there is moderate inflation in an economy then economic activities are likely to be financed; however, distortion in the economy is created if there is high inflation. Similarly, depression in economic growth occurs whenever there is double-digit inflation, while on the same time it is good for economic growth whenever it is in single-digit.

\section{2- Specification for different continents from 1997-2006}

Table-5 reports the estimation results of fixed effect model, random effect model, and GMM for grouped and ungrouped data for the time period of 1997-2006. From goup-I to III, the suitable technique is fixed effect suggested by Hausman test, however, for group-IV to random effect is appropriate option.

Negative and significant relationship between external debt and GDP growth is for group-I, II, and IV, however the coefficients are not significant for group-III and group-V countries though the values are negative. Similarly, 
the coefficients of debt-servicing are negative and significant for all groups of countries (except group-V) which imply the existence of crowding out effect.

The positive role of investment in GDP growth is confirmed in this study whereby the coefficients are positive and significant for group-I, II, and IV, however, the coefficients remains insignificant for group-III and V though the values are positive. The likely growth enhancing effect of trade openness seems to be due to the increased productivity and competitiveness in the period of 1997-2017.

The results of urbanization for all the groups are significant and positive for all groups except the group-III. The estimation results of inflation for the period of 1997-2006 reports that for group-I,II,III the results are positive and significant, however, the estimated coefficient for group-IV is positive and insignificant. On the other hand, inflation negative and significantly affect the growth in group-V countries.

\section{3- Specification for different continents from 1997-2006}

Table-6 reports the estimation results of fixed effect model, random effect model, and GMM for grouped and ungrouped data for the time period of 1997-2006. From group-I to IV, the suitable technique is fixed effect model suggested by Hausman test, however, for group- $V$ the random effect model is appropriate option.

The estimation results for the post financial crisis period (2007-2017) endorsed the negative and significant relationship between external debt and GDP growth for all group of countries. Similarly, the coefficients of debtservicing are negative and significant for group-I,II, and V; but, the coefficient is insignificant for group-III and IV countries.

The positive role of investment in GDP growth is confirmed in this study whereby the coefficients are positive and significant for group-I, II, and IV, however, the coefficients remains insignificant for group-III and V though the values are positive. The likely growth enhancing effect of trade openness seems to be due to the increased productivity and competitiveness in the period of 2007 to 2017 for all groups of countries.

The results of urbanization for all the groups are significant and positive for all groups except the group-III. The estimation results of inflation for the period of 2007-2017 reports that for group-I and II the results are positive and significant, however, the estimated coefficient for group-IV is positive and insignificant. On the other hand, the coefficients of inflation for group-III and V countries are negative but insignificant.

\section{Conclusions and policy implications}

The aim of the study is to analyze the pre and post financial crisis 2008 effects of external debt on economic growth. The findings of the study show that external debt has a negative effect on GDP growth of all BRI countries for the period of 1997 to 2017, however, at ungroup level it affect only African and South American countries. On the pre-financial crisis period identify negative relationship between external debt and GDP growth for all BRI, Asian, and African countries. Similar finding are derived from the post-financial crisis period which reports that external debt significantly affect negatively the growth performance negative of all the countries.

The analysis of the study reports that debt servicing negatively influence all countries growth performance, however, the pre-financial crisis period analysis shows that all countries are affected negatively except the South American countries. Similarly, the post-financial crisis period identify that growth in all countries are negatively affected by debt servicing, however, it doesn't affect European and African countries.

Regarding the impact of domestic investment on growth of BRI countries, the estimation results report that for the full sample period the domestic investment positively contribute to growth performance in all BRI countries and Europe. Similarly, the pre \& post-financial crisis period analysis identify that domestic also contribute here positively to growth performance of all BRI courtiers as well as the ungrouped BRI countries-e.g., Asia, and Africa.

The coefficients of trade openness in all the specifications for the grouped and ungrouped data support the view that it positively contribute to the economic growth. This seems to be due to the increased competition and efficiency. Role of inflation in economic is not unambiguous in our estimation. It may positive or negatively contributes the economic growth. The post-financial crisis period estimation results show that it affect favorably the growth in BRI specifically in Asia countries.

In all specifications for BRI countries, urbanization play a positive role. However, the role of urbanization in European economies is insignificant but according the economic the coefficients values are positive. 


\begin{tabular}{|c|c|c|c|c|c|c|c|c|c|c|}
\hline \multicolumn{11}{|c|}{ Table-4. Estimation results for the period of 1997-2017 } \\
\hline \multirow{2}{*}{$\begin{array}{l}\text { Explanatory } \\
\text { Variables }\end{array}$} & \multicolumn{2}{|c|}{ Global Group-I } & \multicolumn{2}{|c|}{ Group-II Asia } & \multicolumn{2}{|c|}{ Group-III Europe } & \multicolumn{2}{|c|}{ Group-IV Africa } & \multicolumn{2}{|c|}{$\begin{array}{c}\text { Group-V South } \\
\text { America }\end{array}$} \\
\hline & $F E$ & GMM & $F E$ & GMM & $F E$ & GMM & $F E$ & GMM & $R E$ & $G M M$ \\
\hline $\begin{array}{l}\text { External debt } \\
(E D T)\end{array}$ & $\begin{array}{c}-0.02 * * \\
(0.01)\end{array}$ & $\begin{array}{c}-0.03 * * * \\
(0.01)\end{array}$ & $\begin{array}{l}-.00 \\
(.01)\end{array}$ & $\begin{array}{c}0.00 \\
(0.01)\end{array}$ & $\begin{array}{l}-0.00 \\
(0.03)\end{array}$ & $\begin{array}{c}0.12 \\
(0.16)\end{array}$ & $\begin{array}{c}-.06 * * * \\
(.01)\end{array}$ & $\begin{array}{c}0.08^{* * * *} \\
(0.02)\end{array}$ & $\begin{array}{c}-0.07 * \\
(.05)\end{array}$ & $\begin{array}{c}0.06 \\
(0.05)\end{array}$ \\
\hline $\begin{array}{l}\text { Investment } \\
(D I)\end{array}$ & $\begin{array}{l}0.03 * \\
(0.03) \\
\end{array}$ & $\begin{array}{l}0.01^{*} \\
(0.01)\end{array}$ & $\begin{array}{c}0.02 \\
(0.03)\end{array}$ & $\begin{array}{c}0.02 \\
(0.02) \\
\end{array}$ & $\begin{array}{l}0.02^{*} \\
(0.05)\end{array}$ & $\begin{array}{l}0.14^{*} \\
(0.08)\end{array}$ & $\begin{array}{l}-0.04 \\
(0.05) \\
\end{array}$ & $\begin{array}{c}0.02 \\
(0.04) \\
\end{array}$ & $\begin{array}{c}0.06 \\
(0.07) \\
\end{array}$ & $\begin{array}{l}0.04 \\
(0.06) \\
\end{array}$ \\
\hline $\begin{array}{l}\text { Debt Servicing } \\
(D S)\end{array}$ & $\begin{array}{c}-0.12 * * * \\
(0.03)\end{array}$ & $\begin{array}{c}-0.13 * * * \\
(0.01)\end{array}$ & $\begin{array}{c}-.10^{* *} \\
(.05)\end{array}$ & $\begin{array}{l}0.01^{*} \\
(0.01)\end{array}$ & $\begin{array}{c}- \\
\left(0.23^{* * *}\right. \\
(0.07)\end{array}$ & $\begin{array}{c}0.22 * * * \\
(0.04)\end{array}$ & $\begin{array}{c}(0.13 * * \\
(.06)\end{array}$ & $\begin{array}{l}0.12 * * \\
(0.05)\end{array}$ & $\begin{array}{l}0.19^{*} \\
(0.11)\end{array}$ & $\begin{array}{l}0.14^{*} \\
(0.09)\end{array}$ \\
\hline $\begin{array}{l}\text { Inflation } \\
(I N F)\end{array}$ & $\begin{array}{l}-0.01 \\
(0.01)\end{array}$ & $\begin{array}{c}-0.04 * * * \\
(0.00)\end{array}$ & $\begin{array}{l}-0.00 \\
(0.00)\end{array}$ & $\begin{array}{c}- \\
0.03^{* * * *} \\
(0.01) \\
\end{array}$ & $\begin{array}{c}-0.04 * * * \\
(0.01)\end{array}$ & $\begin{array}{c}0.03 \\
(0.02)\end{array}$ & $\begin{array}{l}-0.02^{*} \\
(0.01)\end{array}$ & $\begin{array}{c}0.03 * * * \\
(0.01)\end{array}$ & $\begin{array}{c}-.06 \\
(0.05)\end{array}$ & $\begin{array}{l}0.10^{* *} \\
(0.05)\end{array}$ \\
\hline $\begin{array}{l}\text { Openness } \\
(O P E N)\end{array}$ & $\begin{array}{c}0.03 * * * \\
(0.01)\end{array}$ & $\begin{array}{c}0.073^{* * *} * \\
(0.00)\end{array}$ & $\begin{array}{c}0.03 * * * \\
(0.00)\end{array}$ & $\begin{array}{c}0.06^{* * *} \\
(0.01)\end{array}$ & $\begin{array}{c}0.12 * * * \\
(0.02)\end{array}$ & $\begin{array}{c}0.08^{* * * *} \\
(0.02)\end{array}$ & $\begin{array}{c}0.10 * * * \\
(0.03)\end{array}$ & $\begin{array}{c}0.05^{* *} \\
(0.03)\end{array}$ & $\begin{array}{c}0.05 * * * \\
(0.01)\end{array}$ & $\begin{array}{l}0.06^{* * * *} \\
(0.01)\end{array}$ \\
\hline $\begin{array}{l}\text { Urbanisation } \\
(\text { URB) }\end{array}$ & $\begin{array}{c}0.22 * * * \\
(0.06) \\
\end{array}$ & $\begin{array}{c}0.05 * * * \\
(0.01)\end{array}$ & $\begin{array}{l}0.17 * * \\
(0.08) \\
\end{array}$ & $\begin{array}{c}0.23 * * * \\
(0.03) \\
\end{array}$ & $\begin{array}{c}-0.44 * * * \\
(0.15) \\
\end{array}$ & $\begin{array}{l}1.03 * \\
(0.86) \\
\end{array}$ & $\begin{array}{l}0.19^{*} \\
(0.19) \\
\end{array}$ & $\begin{array}{c}0.21 \text { *** } \\
(0.05)\end{array}$ & $\begin{array}{l}0.84^{*} \\
(0.51) \\
\end{array}$ & $\begin{array}{l}1.14 * * \\
(0.5) \\
\end{array}$ \\
\hline Cons & $\begin{array}{c}14.14^{* * * *} \\
(3.04)\end{array}$ & $\begin{array}{c}1.29 * * * \\
(0.97)\end{array}$ & $\begin{array}{c}9.95^{* * *} \\
(3.72)\end{array}$ & $\begin{array}{c}-6.85 \\
* * * \\
(2.64)\end{array}$ & $\begin{array}{c}23.71 * * * \\
(8.40)\end{array}$ & $\begin{array}{c}54.07 \\
(47.22)\end{array}$ & $\begin{array}{l}10.35 \\
(8.09)\end{array}$ & $\begin{array}{c}14.81 * * * \\
(2.22)\end{array}$ & $\begin{array}{c}-49.01 * \\
(31.08)\end{array}$ & $\begin{array}{l}66.56^{* *} \\
(29.92)\end{array}$ \\
\hline $\begin{array}{l}\text { No. of } \\
\text { observations }\end{array}$ & 1,060 & 1,004 & 591 & 559 & 269 & 255 & 140 & 133 & 40 & 38 \\
\hline $\begin{array}{l}\text { Hausman test } \\
\text { (FE vs RE)/ } \\
\text { AR (1) GMM }\end{array}$ & $25.13 * * *$ & $-2.14 * *$ & $14.44 * *$ & $-1.62 *$ & $35.98 * * *$ & $-2.90 *$ & $32.54 * * *$ & & 9.00 & \\
\hline AR (2) GMM & & 0.82 & & 0.76 & & -1.24 & & & & \\
\hline
\end{tabular}

Note: $* * *, * *, *$ represent $1 \%, 5 \%$ and $10 \%$ level of significance. Value in () shows the robust stand errors 


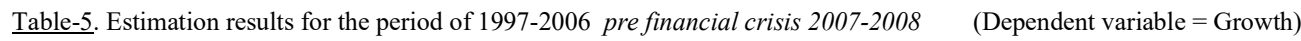

\begin{tabular}{|c|c|c|c|c|c|c|c|c|c|c|}
\hline \multirow{2}{*}{$\begin{array}{l}\text { Explanatory } \\
\text { Variables }\end{array}$} & \multicolumn{2}{|c|}{ Global Group-I } & \multicolumn{2}{|c|}{ Asia } & \multicolumn{2}{|c|}{ Europe } & \multicolumn{2}{|c|}{ Africa } & \multicolumn{2}{|c|}{$\begin{array}{c}\text { Oceania and } \\
\text { America }\end{array}$} \\
\hline & $F E$ & GMM & $F E$ & GMM & $F E$ & GMM & $R E$ & GMM & $R E$ & $G M M$ \\
\hline $\begin{array}{l}\text { Investment } \\
(D I)\end{array}$ & $\begin{array}{r}0.13 * * * \\
(0.04)\end{array}$ & $\begin{array}{l}0.14 * * * \\
(0.03)\end{array}$ & $\begin{array}{r}0.12 \\
(0.06) \\
\end{array}$ & $\begin{array}{l}0.02 * * * \\
(0.03)\end{array}$ & $\begin{array}{c}0.12 \\
(0.09) \\
\end{array}$ & $\begin{array}{c}0.14 \\
(0.18) \\
\end{array}$ & $\begin{array}{c}0.31 * * \\
(.13)\end{array}$ & $\begin{array}{l}0.13 \\
(0.2)\end{array}$ & $\begin{array}{c}0.18 \\
(0.19) \\
\end{array}$ & $\begin{array}{l}0.27 \\
(0.27) \\
\end{array}$ \\
\hline $\begin{array}{l}\text { External debt } \\
(E D T)\end{array}$ & $\begin{array}{r}-0.02 \\
(0.01)\end{array}$ & $\begin{array}{l}0.05 * * * \\
(0.01)\end{array}$ & $\begin{array}{r}-0.02 \\
(0.02)\end{array}$ & $\begin{array}{l}-0.04 * * * \\
(0.01)\end{array}$ & $\begin{array}{l}-0.04 \\
(0.04)\end{array}$ & $\begin{array}{l}-0.07 \\
(0.12)\end{array}$ & $\begin{array}{c}-0.10 * * * \\
(0.02)\end{array}$ & $\begin{array}{c}0.14 * * * \\
(0.04)\end{array}$ & $\begin{array}{l}-0.08 \\
(0.10)\end{array}$ & $\begin{array}{l}0.00 \\
(0.11)\end{array}$ \\
\hline $\begin{array}{l}\text { Debt Servicing } \\
(D S)\end{array}$ & $\begin{array}{r}-0.10^{* * *} \\
(0.05) \\
\end{array}$ & $\begin{array}{l}0.15 * * * \\
(0.02)\end{array}$ & $\begin{array}{r}-0.05 \\
(0.07) \\
\end{array}$ & $\begin{array}{l}0.02 * * \\
(0.01)\end{array}$ & $\begin{array}{c}-0.47 * * * \\
(0.12)\end{array}$ & $\begin{array}{c}0.18 \\
(0.13) \\
\end{array}$ & $\begin{array}{c}0.17 * * \\
(0.07) \\
\end{array}$ & $\begin{array}{c}0.14 \\
(0.13) \\
\end{array}$ & $\begin{array}{c}0.06 \\
(0.13) \\
\end{array}$ & $\begin{array}{l}0.10 \\
(0.14) \\
\end{array}$ \\
\hline $\begin{array}{l}\text { Inflation } \\
(I N F)\end{array}$ & $\begin{array}{r}0.05 * * * \\
(0.01)\end{array}$ & $\begin{array}{l}0.06 * * * \\
(0.01)\end{array}$ & $\begin{array}{r}0.01 \\
(0.02)\end{array}$ & $\begin{array}{l}0.14 * * * \\
(0.01)\end{array}$ & $\begin{array}{c}0.07 * * * \\
(0.03)\end{array}$ & $\begin{array}{l}0.11 * \\
(0.07)\end{array}$ & $\begin{array}{c}0.01 \\
(0.03)\end{array}$ & $\begin{array}{c}0.03 \\
(0.09)\end{array}$ & $\begin{array}{l}-0.61^{*} \\
(0.43)\end{array}$ & $\begin{array}{l}-0.05 \\
(0.57)\end{array}$ \\
\hline $\begin{array}{l}\text { Openness } \\
(O P E N)\end{array}$ & $\begin{array}{r}0.08 * * * \\
(0.01)\end{array}$ & $\begin{array}{l}0.14 * * * \\
(0.01)\end{array}$ & $\begin{array}{r}0.09 \\
(0.02)\end{array}$ & $\begin{array}{l}0.16 * * * \\
(0.01)\end{array}$ & $\begin{array}{c}0.14 * * * \\
(0.04)\end{array}$ & $\begin{array}{c}0.02 \\
(0.05)\end{array}$ & $\begin{array}{l}.14 * * * \\
(0.04)\end{array}$ & $\begin{array}{c}0.05 \\
(0.04)\end{array}$ & $\begin{array}{l}0.12 * \\
(0.07)\end{array}$ & $\begin{array}{l}0.06 \\
(0.09) \\
\end{array}$ \\
\hline $\begin{array}{l}\text { Urbanisation } \\
(U R B)\end{array}$ & $\begin{array}{r}0.04 \\
(0.16)\end{array}$ & $\begin{array}{l}0.22 * * * \\
(0.03)\end{array}$ & $\begin{array}{r}0.15 \\
(0.21)\end{array}$ & $\begin{array}{l}0.51 * * * \\
(0.07) \\
\end{array}$ & $\begin{array}{c}0.26 \\
(0.39) \\
\end{array}$ & $\begin{array}{c}0.52 \\
(0.87) \\
\end{array}$ & $\begin{array}{c}0.20 * * * \\
(0.05)\end{array}$ & $\begin{array}{c}0.70 \\
(0.72) \\
\end{array}$ & $\begin{array}{l}2.40 * \\
(1.36) \\
\end{array}$ & $\begin{array}{l}1.36 \\
(1.82) \\
\end{array}$ \\
\hline Cons & $\begin{array}{r}2.57 \\
(7.63)\end{array}$ & $\begin{array}{l}6.30 * * * \\
(2.06)\end{array}$ & $\begin{array}{r}-5.30 \\
(9.08)\end{array}$ & $\begin{array}{l} \\
19.77 * * * \\
(4.89) \\
\end{array}$ & $\begin{array}{c}10.29 \\
(21.77)\end{array}$ & $\begin{array}{l}29.99 \\
(47.4)\end{array}$ & $\begin{array}{c}13.52 * * * \\
(2.79)\end{array}$ & $\begin{array}{c}37.46 \\
(31.36)\end{array}$ & $\begin{array}{c}-113.78 * \\
(65.35)\end{array}$ & $\begin{array}{l}90.33 \\
(86.04) \\
\end{array}$ \\
\hline $\begin{array}{l}\text { No. of } \\
\text { observations }\end{array}$ & 530 & 474 & 301 & 269 & 129 & 115 & 70 & 80 & 20 & 16 \\
\hline $\begin{array}{l}\text { Hausman } \\
\text { test/AR(1) }\end{array}$ & $55.96 * * *$ & $-1.55^{*}$ & $37.97 * * *$ & -1.20 & & -1.28 & 7.19 & & 2.53 & \\
\hline $\mathrm{AR}(-2)$ & & 0.64 & & 0.37 & & 0.84 & & & & \\
\hline
\end{tabular}

Note: $* * * * *, *$ represent $1 \%, 5 \%$ and $10 \%$ level of significance. Value in () shows the robust stand errors 
Table-6. Estimation results for the period of 2007-2017, post financial crisis 2007-2008 (Dependent variable $=$ Growth)

\begin{tabular}{|c|c|c|c|c|c|c|c|c|c|c|}
\hline \multirow{2}{*}{$\begin{array}{l}\text { Explanator } \\
\text { y Variables }\end{array}$} & \multicolumn{2}{|c|}{ Global Group-I } & \multicolumn{2}{|c|}{ Asia } & \multicolumn{2}{|c|}{ Europe } & \multicolumn{2}{|c|}{ Africa } & \multicolumn{2}{|c|}{$\begin{array}{c}\text { Oceania and } \\
\text { America }\end{array}$} \\
\hline & $F E$ & $G M M$ & $F E$ & GMM & $F E$ & GMM & $F E$ & $\begin{array}{l}\text { GM } \\
\text { M }\end{array}$ & $R E$ & GMM \\
\hline $\begin{array}{l}\text { Investment } \\
(D I)\end{array}$ & $\begin{array}{r}0.01 \\
(0.03)\end{array}$ & $\begin{array}{l}0.14 * * \\
* \\
(0.02)\end{array}$ & $\begin{array}{l}0.07 * \\
(0.05)\end{array}$ & $\begin{array}{l}0.14 * * \\
* \\
(0.03)\end{array}$ & $\begin{array}{r}0.03 \\
(0.10)\end{array}$ & $\begin{array}{l}0.13 \\
(0.15)\end{array}$ & $\begin{array}{r}0.18 * * \\
(0.08)\end{array}$ & $\begin{array}{l}0.00 \\
(0.06 \\
)\end{array}$ & $\begin{array}{r}0.10 \\
(0.14)\end{array}$ & $\begin{array}{l}0.14 \\
(0.11)\end{array}$ \\
\hline $\begin{array}{l}\text { External } \\
\text { debt }(E D T)\end{array}$ & $\begin{array}{l}-0.04^{*} \\
(0.02)\end{array}$ & $\begin{array}{l}- \\
0.12 * * \\
* \\
(0.02)\end{array}$ & $\begin{array}{r}-0.02 \\
(0.03) \\
\end{array}$ & $\begin{array}{l}- \\
0.11 * * \\
* \\
(0.02)\end{array}$ & $\begin{array}{r}-0.20 * * \\
(0.08) \\
\end{array}$ & $\begin{array}{l}- \\
0.30 * * \\
(0.14) \\
\end{array}$ & $\begin{array}{r}0.20 * * \\
(0.09) \\
\end{array}$ & $\begin{array}{l}-0.01 \\
(0.08 \\
) \\
\end{array}$ & $\begin{array}{r}-0.06 \\
(0.12)\end{array}$ & $\begin{array}{l}- \\
0.34 * * \\
* \\
(0.11) \\
\end{array}$ \\
\hline $\begin{array}{l}\text { Debt } \\
\text { Servicing } \\
(D S)\end{array}$ & $\begin{array}{r}0.25 * * * \\
(0.06)\end{array}$ & $\begin{array}{l}0.34 * * \\
* \\
(0.01)\end{array}$ & $\begin{array}{r}-0.42 \\
* * * \\
(0.11) \\
\end{array}$ & $\begin{array}{l}- \\
0.22 * * \\
* \\
(0.04)\end{array}$ & $\begin{array}{r}-0.06 \\
(0.12)\end{array}$ & $\begin{array}{l}-0.05 \\
(0.08)\end{array}$ & $\begin{array}{r}-0.06 \\
(0.14)\end{array}$ & $\begin{array}{l}-0.06 \\
(0.17 \\
)\end{array}$ & $\begin{array}{l}-0.68^{*} \\
(0.46)\end{array}$ & $\begin{array}{l}-0.88^{* *} \\
(0.38)\end{array}$ \\
\hline $\begin{array}{l}\text { Inflation } \\
(I N F)\end{array}$ & $\begin{array}{r}0.02 * * * \\
(0.01)\end{array}$ & $\begin{array}{l}0.06^{* *} \\
* \\
(0.01)\end{array}$ & $\begin{array}{r}0.05 * * * \\
(0.01) \\
\end{array}$ & $\begin{array}{l}0.05 * * \\
* \\
(0.01)\end{array}$ & $\begin{array}{r}-0.04 \\
(0.02)\end{array}$ & $\begin{array}{l}-0.03 \\
(0.04)\end{array}$ & $\begin{array}{r}0.01 \\
(0.02)\end{array}$ & $\begin{array}{l}0.01 \\
(0.02 \\
) \\
\end{array}$ & $\begin{array}{l}-0.38 \\
(.29)\end{array}$ & $\begin{array}{l}-0.24 \\
(0.22)\end{array}$ \\
\hline $\begin{array}{l}\text { Openness } \\
(O P E N)\end{array}$ & $\begin{array}{r}0.05 * * * \\
(0.01)\end{array}$ & $\begin{array}{l}0.06^{* *} \\
* \\
(0.01)\end{array}$ & $\begin{array}{r}0.03 \\
(0.01)\end{array}$ & $\begin{array}{l}0.06 * * \\
* \\
(0.01)\end{array}$ & $\begin{array}{r}0.17 * * * \\
(0.04)\end{array}$ & $\begin{array}{l}0.18 * * \\
* \\
(0.03)\end{array}$ & $\begin{array}{r}0.12 * * * \\
(0.04)\end{array}$ & $\begin{array}{l}0.02 \\
(0.04 \\
)\end{array}$ & $\begin{array}{r}0.13 * * \\
* \\
(0.05)\end{array}$ & $\begin{array}{l}0.16 * * \\
* \\
(0.04)\end{array}$ \\
\hline $\begin{array}{l}\text { Urbanisatio } \\
\mathrm{n}(U R B)\end{array}$ & $\begin{array}{r}0.63 * * * \\
(0.15)\end{array}$ & $\begin{array}{l}0.02 \\
(0.02)\end{array}$ & $\begin{array}{r}0.95 * * * \\
(0.2)\end{array}$ & $\begin{array}{l}0.05^{*} \\
(0.03)\end{array}$ & $\begin{array}{r}0.23 \\
(0.40)\end{array}$ & $\begin{array}{l}0.18 \\
(0.22)\end{array}$ & $\begin{array}{r}0.99 * * \\
(0.45)\end{array}$ & $\begin{array}{l}0.06 \\
(0.09 \\
\end{array}$ & $\begin{array}{r}6.30 \\
(4.37)\end{array}$ & $\begin{array}{l}4.87^{*} \\
(3.26)\end{array}$ \\
\hline Cons & $\begin{array}{r}30.34 * * \\
* \\
(7.44)\end{array}$ & $\begin{array}{l}5.06^{* *} \\
* \\
(0.56) \\
\end{array}$ & $\begin{array}{l}42.84 \\
* * * \\
(8.78) \\
\end{array}$ & $\begin{array}{l}5.26 * * \\
* \\
(1.46) \\
\end{array}$ & $\begin{array}{r}8.64 \\
(24.38) \\
\end{array}$ & $\begin{array}{l}- \\
24.48^{*} \\
(13.95) \\
\end{array}$ & $\begin{array}{r}41.60 * * \\
(17.95) \\
\end{array}$ & $\begin{array}{l}6.92 \\
* \\
(3.71 \\
)\end{array}$ & $\begin{array}{r}-388.52 \\
(266.53 \\
)\end{array}$ & $\begin{array}{l}306.14 \\
* \\
(198.92 \\
) \\
\end{array}$ \\
\hline $\begin{array}{l}\text { No. of } \\
\text { observation } \\
\text { s }\end{array}$ & 530 & 476 & 290 & 260 & 140 & 126 & 70 & 63 & 20 & 18 \\
\hline $\begin{array}{l}\text { Hausman } \\
\text { test/AR(1) }\end{array}$ & $\begin{array}{c}45.87 * * \\
*\end{array}$ & $\begin{array}{c}- \\
4.33^{* *} \\
*\end{array}$ & $\begin{array}{c}43.32 * * \\
*\end{array}$ & $\begin{array}{c}- \\
2.98 * * \\
*\end{array}$ & $\begin{array}{c}36.72 * * \\
*\end{array}$ & $\begin{array}{c}- \\
2.42 * *\end{array}$ & $\begin{array}{c}31.11 * * \\
*\end{array}$ & & 0.71 & \\
\hline $\mathrm{AR}(-2)$ & & -1.21 & & -1.18 & & $\begin{array}{c}- \\
2.23 * *\end{array}$ & & & & \\
\hline
\end{tabular}

Note: $* * *, * *,{ }^{*}$ represent $1 \%, 5 \%$ and $10 \%$ level of significance. Value in () shows the robust stand errors

\section{References}

Buchanan, J. M. (1966). The ICons of Public Debt. The Journal of Finance, 21(3), 544-546. doi:10.1111/j.1540-6261.1966.tb00256.x

Burnside, C. M., \& Dollar, D. (2000). Aid, Policies, and Growth. American Economic Review, 90(4), 847-868. doi:10.1257/aer.90.4.847

Baltagi, B. H. (2005). Econometric Analysis of Panel Data (3rd ed.). West Sussex: John Wiley \& Sons.

Chowdhury, A. R. (2001). External debt and growth in developing countries; a sensitivity and causal analysis (Discussion Paper No. 2001/95): WIDER

Cohen, D. (1993). Low investment and large lcd debt in the 1980's. The American Economic Review, 83, 437449. 
Elbadawi, I. A., Benno, J. N., \& Njuguna, N. U. (1999). Debt overhang and economic growth in Sub-Saharan Africa. Chapter 5. In Iqbal Zubair \& Ravi Kanbur (Eds.), External Finance for Low-Income Countries, pp. 49-76. Washington, DC: IMF Institute.

Enders, W. (2004). Applied Econometrics: Time Series. New Jersey: John Wiley \& Sons.

Haque, N. U., \& Nayab, D. (2006). Renew Cities to be the Engine of Growth. The Pakistan Development Review, 45(3), 505-509. doi:10.30541/v45i3pp.505-509

Karagol, E. (2002). The causality analysis of external debt service and GNP. The Case of Turkey", Central Bank Review, 39-64.

Krugman, P. (1988). Financing vs. forgiving a debt overhang. Journal of Development Economics, 29(3), 253268. doi:10.1016/0304-3878(88)90044-2

Lucas, R. E. (1988). On the mechanics of economic development. Journal of Monetary Economics, 22(1), 3-42. doi:10.1016/0304-3932(88)90168-7

Mankiw, N. G., Romer, D., \& Weil, D. N. (1992). A Contribution to the Empirics of Economic Growth. The Quarterly Journal of Economics, 107(2), 407-437. doi:10.2307/2118477

Murray, M. P. (2006). Avoiding Invalid Instruments and Coping with Weak Instruments. Journal of Economic Perspectives, 20(4), 111-132. doi:10.1257/jep.20.4.111

Nguyen, T. Q., Clements, B. J., \& Bhattacharya, R. (2003). External Debt, Public Investment, and Growth in Low-Income Countries. IMF Working Papers, 03(249), 1. doi:10.5089/9781451875904.001

Poirson, H., Ricci, L. A., \& Pattillo, C. A. (2002). External Debt and Growth. IMF Working Papers, 02(69), 1. doi:10.5089/9781451849073.001

Poirson, H., Ricci, L. A., \& Pattillo, C. A. (2004). What Are the Channels Through Which External Debt Affects Growth? IMF Working Papers, 04(15), 1. doi:10.5089/9781451843293.001

Reinhart, C. M., \& Rogoff, K. S. (2010). Growth in a Time of Debt. American Economic Review, 100(2), 573578. doi: $10.1257 /$ aer.100.2.573 